\title{
FAKTOR-FAKTOR YANG MEMPENGARUHI KINERJA KELOMPOK TANI HUTAN MITRA UPT KPHP MINAS TAHURA
}

\section{The Influence Factors Of The Forest Farmers Group Performance As Partners Of UPT KPHP Minas Tahura}

\author{
Dian Gustika $^{1}$, Eno Suwarno $^{2}$, Enny Insusanty $^{2}$ \\ ${ }^{1}$ Fakultas Kehutanan Universitas Lancang Kuning \\ ${ }^{2}$ Staf Pengajar Fakultas Kehutanan Universitas Lancang Kuning \\ Jln. Yos Sudarso Km. 8 Rumbai Pekanbaru Telp (0761) 54092
}

Email:diangustika@gmail.com; enosuwarno@unilak.ac.id; ennyinsusanty@unilak.ac.id

Diterima: 14 Februari 2020, Direvisi: 17 Maret 2020, Disetujui: 17 Maret 2020

DOI: https://doi.org/10.31849/forestra

\begin{abstract}
The UPT KPHP Minas Tahura is obliged to participate in developing communities around the forest area of its working area which is incorporated in the Forest Farmer Group (KTH). Until now, the performance of KTH is still considered low in managing its members and farming. This study aims to find important factors that influence KTH performance and identify the types of programs that can improve KTH performance. The study was conducted in 4 KTH in Bekalar Village and Belutu Village in Riau Province. The study was conducted using a questionnaire method involving 62 respondents who were analyzed using the Partial Least Square approach. The results showed $67.10 \%$ of respondents answered the level of performance of KTH was classified as Moderate. There are 3 factors that have a significant effect on KTH performance, namely group dynamics, member participation and characteristics of group leaders, while the other 3 factors are member characteristics, the role of the instructor and the UPT KPHP Minas Tahura have no significant effect. Furthermore the aspects that it can support the performance of forest farmer groups were (a) institutional strengthening, (b) enhancing guidance, (c) increasing the ability of farmer group members, and $(d)$ increasing the number of visits, monitoring and evaluation by the UPT KPHP Minas Tahura.
\end{abstract}

Keywords : Forest Farmer Group (KTH), Performance, UPT KPHP Minas Tahura

\begin{abstract}
ABSTRAK
UPT KPHP Minas Tahura berkewajiban ikut membina masyarakat di sekitar kawasan hutan areal kerjanya yang tergabung dalam Kelompok Tani Hutan (KTH). Saat ini kinerja KTH dinilai belum optimal dalam mengelola anggota dan usahataninya. Penelitian ini bertujuan untuk menemukan faktor-faktor penting yang mempengaruhi kinerja KTH dan mengidentifikasi jenis-jenis program yang dapat meningkatkan kinerja KTH. Penelitian dilaksanakan pada 4 KTH di Desa Bekalar dan Desa
\end{abstract}


Belutu Kecamatan Kandis, Kabupaten Siak, Provinsi Riau. Penelitian dilaksanakan dengan metode kuesioner yang melibatkan 62 orang responden. Data dianalisis dengan pendekatan Partial Least Square (PLS). Hasil penelitian menunjukkan $67,10 \%$ responden menjawab tingkat kinerja KTH tergolong Sedang. Terdapat 3 faktor yang berpengaruh signifikan terhadap kinerja KTH yaitu kedinamisan kelompok, partisipasi anggota dan karakteristik ketua kelompok, sedangkan 3 faktor lainnya yaitu karakteristik anggota, peran penyuluh dan peran UPT KPHP Minas Tahura tidak berpengaruh signifikan. Selanjutnya aspek yang dapat mendukung kinerja KTH yaitu (a) penguatan kelembagaan, (b) peningkatkan pembinaan, (c) peningkatan kemampuan anggota kelompok tani, dan (d) peningkatan jumlah kunjungan, monitoring dan evaluasi oleh UPT KPHP Minas Tahura.

Kata Kunci : Kelompok Tani Hutan (KTH), kinerja, UPT KPHP Minas Tahura.

\section{PENDAHULUAN}

KPHP Minas Tahura merupakan salah satu lembaga teknis pemerintah yang bertugas untuk mengelola hutan di tingkat tapak. Wilayah kerjanya berada di Provinsi Riau, ditetapkan berdasarkan Keputusan Menteri Kehutanan Nomor: SK.765/ Menhut-VII/2012 tanggal 26 Desember 2012 seluas \pm 146.734 Ha. Selanjutnya berdasarkan Keputusan Menteri Lingkungan Hidup dan Kehutanan Republik Indonesia Nomor SK. 470/MENLHK/ SETJEN/ PLA.0/7/2019 tanggal 18 Juli 2019 terjadi perubahan luas menjadi 107.795 Ha. Wilayah tersebut terdiri dari Hutan Produksi Terbatas (HPT) \pm 11.241 Ha, Hutan Produksi (HP) seluas \pm 90.382 Ha dan Taman Hutan Raya Sultan Syarif Hasim (Tahura SSH) seluas 6.172 Ha. Tahura SSH sebagai kawasan konservasi, saat ini sebagian besar tutupan lahannya telah berubah menjadi perkebunan kelapa sawit, hanya tinggal 2.087 Ha yang masih berhutan (Suwarno et al., 2018a). Hal ini antara lain disebabkan oleh perambahan hutan yang dilakukan oleh masyarakat. Masyarakat yang tinggal di dekat kawasan hutan ataupun pendatang akan mengakses hutan secara ilegal umumnya karena alasan kurangnya peluang ekonomi. Di negara berkembang seperti Indonesia, deforestasi sering disebabkan oleh faktor sosial, ekonomi, dan budaya (Suwarno et al., 2018b), atau juga karena pengaruh kebijakan yang tidak tepat (Siswoko, 2008; Soe \& Yeo-Chang, 2019).

Tujuan dibentuknya KPH antara lain dalam rangka mengurangi tingkat deforestasi dan degradasi hutan serta mendorong penerapan sistem pengelolaan hutan yang berkelanjutan. Salah satu upaya yang ditempuh oleh KPH adalah melibatkan masyarakat yang berada di dalam dan sekitar kawasan hutan. Sebagai upaya untuk meningkatkan kapasitas masyarakat menuju kemandirian, maka dilakukan program pemberdayaan masyarakat berupa pendampingan dan fasilitasi kegiatan budidaya lebah madu dan budidaya tanaman lada. Melalui kegiatan tersebut diharapkan masyarakat tumbuh dan berkembang menjadi pelaku dan pendukung pembangunan kehutanan.

Kelompok Tani Hutan (KTH) adalah kelompok tani yang beranggotakan 
masyarakat yang berada di dalam dan sekitar kawasan hutan. KPH berkewajiban ikut membina KTH melalui programprogram pemberdayaan masyarakat, dengan tujuan selain untuk meningkatkan taraf hidup anggotanya juga sekaligus dalam rangka perlindungan hutan. Melalui kegiatan pemberdayaan diharapkan tekanan masyarakat terhadap kawasan hutan bisa berkurang, bahkan menjadi mitra KPH dalam perlindungan hutan.

Hingga tahun 2019 KPHP Minas Tahura sudah membina 31 KTH. Akan tetapi dari jumlah $31 \mathrm{KTH}$ tersebut belum semuanya aktif. Pada tahun 2017 ada empat KTH yang telah diberikan pelatihan dan bantuan oleh KPHP Minas Tahura, yaitu KTH Jaya Mandiri, KTH Bangun Jaya, KTH Cahaya Tani dan KTH Jaya Lestari. KTH tersebut sudah menghasilkan produk berupa madu dan buah lada.

Namun demikian, kinerja keempat KTH tersebut dinilai belum optimal. Indikasinya antara lain dilihat dari belum optimalnya hasil usahatani yang telah difasilitasi oleh KPHP Minas Tahura. Rendahnya peran kelompok tani merupakan salah satu penyebab ketidakoptimalnya kinerja KTH dalam pengelolaan organisasi dan kegiatan usaha taninya. Oleh karena itu perlu dilakukan analisis terhadap faktor-faktor yang mempengaruhi kinerja KTH dan kegiatan yang dapat meningkatkan kinerja KTH. Penelitian ini bertujuan untuk (1) menganalisa faktor-faktor yang mempengaruhi kinerja kelompok tani hutan, dan (2) menganalisa aspek kegiatan dari UPT KPHP Minas Tahura yang dapat mendukung kinerja kelompok tani hutan.

\section{METODE PENELITIAN}

\section{Waktu dan Tempat Penelitian}

Penelitian dilaksanakan pada bulan September 2019 sampai dengan Oktober 2019. Penelitian dilakukan di Desa Belutu dan Desa Bekalar Kecamatan Kandis Kabupaten Siak.

\section{Metode Pengumpulan Data}

Sasaran penelitian adalah pengurus dan anggota KTH Jaya Mandiri dan KTH Bangun Jaya di Desa Belutu; KTH Cahaya Tani dan KTH Jaya Lestari di Desa Bekalar. Pengumpulan data dilakukan dengan membagikan kuesioner. Jumlah sampel diambil dari keseluruhan jumlah populasi anggota KTH yaitu berjumlah 62 orang. Adapun sebaran jumlah responden tersebut sebagaimana pada tabel 1 .

Tabel 1. Jumlah responden pada 4 KTH

\begin{tabular}{|c|c|c|}
\hline No & $\begin{array}{c}\text { Nama } \\
\text { Kelompok Tani Hutan }\end{array}$ & $\begin{array}{c}\text { Jumlah } \\
\text { Responden }\end{array}$ \\
\hline 1. & KTH Jaya Mandiri & 15 \\
\hline 2. & KTH Bangun Jaya & 15 \\
\hline 3. & KTH Cahaya Tani & 16 \\
\hline 4. & KTH Jaya Lestari & 16 \\
\hline & Jumlah & 62 \\
\hline
\end{tabular}

Variabel-variabel dalam penelitian ini terdiri dari kinerja kelompok tani (Y) sebagai variabel terpengaruh/terikat dan 6 variabel sebagai variabel mempengaruhi/bebas yaitu kedinamisan kelompok tani (X1), Partisipasi Anggota (X2), Karakteristik Ketua Kelompok (X3), 
Karakteristik Anggota (X4), Peran Penyuluh (X5), dan Peran UPT KPHP Minas Tahura (X6).

Dalam kuesioner disusun pernyataan dan jawaban setiap variabel berupa katakata dengan 5 pilihan skala likert dari yang terendah ke yang tertinggi yaitu : Sangat Rendah, Rendah, Sedang, Tinggi dan Sangat Tinggi. Menurut Sugiyono (2012) skala likert adalah skala yang digunakan untuk mengukur sikap, pendapat, dan persepsi seseorang atau sekelompok orang tentang fenomena sosial.

\section{Analisis Data}

Selanjutnya, data ditabulasikan ke dalam program Microsoft Excel 2007 dan pengujian dianalisis dengan pendekatan Partial Least Square (PLS) yang merupakan bagian dari Structural Equation Modelling (SEM) menggunakan program SmartPLS 3.

a. Analisa Outer Model, sebuah penelitian merupakan suatu model pengukuran yang digunakan untuk menilai validitas dan reliabilitas model (Hartono dan Abdillah, 2009 dalam Ikhsania Z, 2015). Adapaun indikator pengujian dalam outer model adalah sebagai berikut:

1. Convergent Validity adalah indikator yang dinilai berdasarkan korelasi antara item score/komponen score dengan construct score, yang dapat dilihat dari standard loading faktor yang mana menggambarkan besarnya korelasi antar setiap item pengukuran (indikator) dengan konstraknya. Ukuran refleksif individual dikatakan tinggi jika berkorelasi > 0.7 dengan konstruk yang ingin diukur.
2. Discriminant Validity merupakan model pengukuran dengan refleksif indikator dinilai berdasarkan crossloading pengukuran dengan konstruk. Jika korelasi konstruk dengan item pengukuran lebih besar daripada ukuran konstruk lainnya, maka menunjukan ukuran blok mereka lebih baik dibandingkan dengan blok lainnya. Sedangkan menurut metode lain untuk menilai discriminant validity yaitu dengan membandingkan nilai square root of average variance extracted (AVE).

3. Composite Reliability merupakan indikator untuk mengukur suatu konstruk yang dapat dilihat pada view latent variable coefficients. Untuk mengevaluasi composite reliability terdapat dua alat ukur yaitu internal consistency dan cronbach's alpha. Dalam pengukuran tersebut apabila nilai yang dicapai adalah > 0,70 maka dapat dikatakan bahwa konstruk tersebut memiliki reliabilitas yang tinggi

4. Cronbach's Alpha merupakan uji reliabilitas yang dilakukan memperkuat hasil dari composite reliability. Suatu variabel dapat dinyatakan reliabel apabila memiliki nilai cronbach's alpha $>0,7$.

b. Analisa Inner Model, merupakan uji reliabilitas yang dilakukan memperkuat hasil dari composite reliability. Suatu variabel dapat dinyatakan reliabel apabila memiliki nilai cronbach's alpha $>0,7$.

c. Uji Signifikansi, Jogiyanto dan Abdillah (2009) menjelaskan bahwa ukuran signifikansi dapat digunakan 
perbandingan nilai T-table dan $\mathrm{T}$ statistic. Pada penelitian ini, menggunakan nilai statistik untuk alpha $5 \%$ nilai t-statistik yang digunakan adalah 1,96. Sehingga kriteria signifikansinya variabel penelitian ketika t-statistik > 1,96 atau jika nilai $\mathrm{p}$ $<0,05$.

\section{HASIL DAN PEMBAHASAN}

\section{Gambaran Umum Lokasi Penelitian}

\section{Desa Belutu}

Desa Belutu berdiri pada tahun 2002. Memiliki luas $241.743 \mathrm{Ha}$ yang terletak dalam wilayah kecamatan Kandis. Batasbatas wilayah Desa Belutu adalah Sebelah Utara berbatasan dengan Desa Pencing Bekulo, sebelah Timur berbatasan dengan Desa Sungai Mandau, sebelah Selatan berbatasan dengan Desa Sungai Gondang dan sebelah Barat berbatasan dengan Desa Adat Sakai Bekalar.

Jumlah penduduk Desa Belutu 5.798 orang dengan jumlah laki-laki 2.934 orang dan perempuan 2.864 orang. Jumlah Kepala Keluarga 1.404 KK. Penduduk Desa Belutu sebagian besar berasal dari Melayu dan sebagian kecil dari Suku Batak dan Suku Jawa. Mata pencaharian utama penduduk Desa Belutu adalah bertani.

Kelompok Tani Hutan (KTH) yang telah terbentuk di Desa Belutu sebagai berikut:

a. Kelompok Tani Hutan Jaya Lestari, dibentuk melalui Surat Keputusan Pemerintah Desa Belutu Nomor: 56/SK.Pem.Kam.Blt/XI/2017 pada tanggal 3 November 2017. Jumlah anggota KTH 16 orang.

b. Kelompok Tani Hutan Cahaya Tani, dibentuk melalui Surat Keputusan Pemerintah Desa Belutu Nomor: 57/SK.Pem.Kam.Blt/XI/2017 pada tanggal 3 November 2017. Jumlah anggota KTH 16 orang.

\section{Desa Bekalar}

Desa Bekalar berdiri pada tahun 2010 dengan luas wilayah $8.471 \mathrm{Ha}$. Terletak dalam wilayah Kecamatan Kandis dengan jarak $15 \mathrm{Km}$ dengan Pusat Pemerintahan Kecamatan. Batas-batas wilayah Desa Bekalar sebelah Utara berbatasan dengan Desa Jambai Makmur, sebelah Timur berbatasan dengan Desa Belutu, sebelah Selatan berbatasan dengan Desa Minas Barat dan sebelah Barat berbatasan dengan Simpang Belutu.

Jumlah penduduk Desa Bekalar 5.279 orang. Jumlah laki-laki 2.789 orang dan jumlah perempuan adalah 2.490 orang dengan jumlah Kepala Keluarga 1.424 KK. Penduduk Desa Bekalar sebagian besar berasal dari Melayu yang dan sebagian kecil dari Batak dan Suku Jawa. Mata pencaharian utama penduduk Desa Bekalar adalah bertani dan berkebun.

Kelompok Tani Hutan (KTH) yang telah dibentuk di Desa Bekalar adalah:

a. Kelompok Tani Hutan Bangun Jaya, dibentuk melalui Surat Keputusan Pemerintah Desa Bekalar Nomor: 47/SK/KB/2017 pada tanggal 1 November 2017. Jumlah anggota KTH 15 orang. 
b. Kelompok Tani Hutan Jaya Mandiri, dibentuk melalui Surat Keputusan Pemerintah Desa Bekalar Nomor: 48/SK/KB/2017 pada tanggal 1 November 2017. Jumlah anggota KTH 15 orang.

\section{Jawaban Responden Terhadap Kuesioner}

\section{Kinerja Kelompok Tani Hutan}

Berdasarkan tanggapan responden mengenai variabel kinerja $\mathrm{KTH}$, rata-rata responden menjawab tingkat kinerja $\mathrm{KTH}$ masih dalam kategori sedang yaitu sebesar $53,55 \%$.

\section{Kedinamisan Kelompok}

Berdasarkan tanggapan responden mengenai variabel kedinamisan KTH ratarata responden menjawab kedinamisan KTH masih dalam kategori sedang yaitu sebesar $75,48 \%$.

\section{Partisipasi Anggota}

Berdasarkan tanggapan responden terkait partisipasi anggota KTH mayoritas tanggapan responden adalah rendah yaitu sebesar $43,55 \%$.

\section{Karakteristik Ketua Kelompok}

Berdasarkan tanggapan responden terkait karakteristik ketua kelompok, mayoritas tanggapan responden terhadap karakteristik ketua KTH sebagai koordinator, motivator dan inspirator adalah sedang yaitu sebesar $46,24 \%$.

\section{Karakteristik Anggota}

Mayoritas tanggapan responden terhadap karakteristik anggota KTH adalah sedang yaitu sebesar $37,10 \%$.

\section{Peran Penyuluh}

Peran penyuluh sudah tergolong tinggi, hal tersebut dapat dilihat dari tanggapan responden dimana mayoritas tanggapan responden terhadap peran penyuluh adalah tinggi yaitu sebesar $58,47 \%$.

\section{Peran UPT KPHP Minas Tahura}

Berdasarkan tanggapan responden terkait peran UPT KPHP Minas Tahura sudah tinggi, dimana mayoritas tanggapan responden terhadap peran penyuluh adalah tinggi yaitu sebesar 58,47\%.

\section{Faktor-Faktor Yang Mempengaruhi Kinerja KTH}

Setelah dilakukan uji validasi dan reabilitas menggunakan program SmartPLS 3 dengan teknik analisis pendekatan Partial Least Square (PLS), diketahui bahwa instrumen dalam penelitian ini dapat dikatakan valid dan reliable dengan nilai koefisien $>0,7$. Selanjutnya, berdasarkan pengujian model struktural diperoleh nilai R-square sebesar 0,727. Artinya, kedinamisan kelompok, partisipasi anggota, karekteristik ketua, karakteristik anggota, peran penyuluh dan peran KPHP Minas Tahura memberikan pengaruh kepada kinerja KTH sebesar 0,727 atau $72,70 \%$. 
Adapun model persamaan struktural pengaruh enam faktor terhadap kinerja KTH adalah sebagai berikut:

$$
\begin{aligned}
Y=0,265 X 1 & +0,300 X 2+0,343 X 3 \\
& +0,092 X 4+0,058 X 5 \\
& +0,020 X 6
\end{aligned}
$$

$$
\mathrm{R}^{2}=0,727
$$

Berdasarkan persamaan struktural di atas, dapat diketahui besarnya kontribusi keenam faktor tersebut terhadap kinerja KTH. Dalam persamaan tersebut, tercantum koefisien yang menunjukan besarnya pengaruh variabel $\mathrm{X}$ terhadap variabel Y. Secara bersama, pengaruh variabel kedinamisan kelompok, partisipasi anggota, karekteristik ketua, karakteristik anggota, peran penyuluh dan peran KPHP Minas Tahura terhadap variabel kinerja KTH yaitu 0,727 atau $72,70 \%$. Sedangkan sisanya sebesar $27,30 \%$ dijelaskan oleh faktor lain (yang belum terdapat di dalam model).

Selanjutnya, berdasarkan hasil uji signifikansi yang dilakukan, maka diperoleh hasil 3 faktor yang mempengaruhi signifikan terhadap kinerja kelompok tani hutan yaitu kedinamisan kelompok, partisipasi anggota dan karakteristik ketua kelompok. Sedangkan 3 faktor lainnya tidak berpengaruh secara signifikan. Adapun nilai dari hasil uji signifikansi dapat dilihat sebagaimana pada tabel 2 .

Tabel 2. Uji Signifikansi

\begin{tabular}{|l|c|c|c|c|}
\hline \multicolumn{1}{|c|}{ Pengaruh } & $\begin{array}{c}\text { Original } \\
\text { Sample (O) }\end{array}$ & $\begin{array}{c}\text { T Statistics } \\
(\mid \mathbf{O} / \mathbf{S T D E V})\end{array}$ & P Values & Hasil \\
\hline $\begin{array}{l}\text { Kedinamisan -> } \\
\text { Kinerja }\end{array}$ & 0,265 & 2,303 & 0,022 & Signifikan \\
\hline $\begin{array}{l}\text { Partisipasi Anggota -> } \\
\text { Kinerja }\end{array}$ & 0,300 & 2,034 & 0,042 & Signifikan \\
\hline $\begin{array}{l}\text { Karakteristik Ketua } \\
\text { Kelompok -> Kinerja }\end{array}$ & 0,343 & 2,983 & 0,003 & Signifikan \\
\hline $\begin{array}{l}\text { Karakteristik Anggota } \\
>\text { Kinerja }\end{array}$ & 0,092 & 1,114 & 0,266 & $\begin{array}{c}\text { Tidak } \\
\text { Signifikan }\end{array}$ \\
\hline $\begin{array}{l}\text { Peran Penyuluh -> } \\
\text { Kinerja }\end{array}$ & 0,058 & 0,665 & 0,506 & $\begin{array}{c}\text { Tidak } \\
\text { Signifikan }\end{array}$ \\
\hline $\begin{array}{l}\text { Peran KPHP -> } \\
\text { Kinerja }\end{array}$ & 0,020 & 0,208 & 0,835 & $\begin{array}{c}\text { Tidak } \\
\text { Signifikan }\end{array}$ \\
\hline
\end{tabular}

Sumber: Pengolahan data dengan SmartPLS, 2019

\section{Pengaruh Kedinamisan Kelompok Terhadap Kinerja KTH}

Berdasarkan hasil uji signifikansi, Kedinamisan Kelompok berpengaruh signifikan terhadap Kinerja KTH. Kedinamisan merupakan hal-hal yang berkaitan dengan tingkat kekompakan, kejelasan fungsi, peran, tujuan dan struktur serta suasana kelompok. Rendahnya Kedinamisan Kelompok akan menyebabkan rendahnya Kinerja dari KTH.

Wawancara secara mendalam dengan pengurus Kelompok di setiap kelompok tani hutan mengemukakan hal yang sama yaitu kelompok tani hutan memiliki struktur dan tujuan yang jelas, namun belum berjalan sesuai dengan harapan. Struktur kelompok hanya menjadi syarat sebuah kelompok sehingga menyebabkan fungsi, peran dan tujuan kelompok menjadi rendah. Disamping itu, juga belum terbentuknya kekompakan diantara sesama anggota kelompok serta suasana kelompok yang masih kaku sehingga hal-hal tersebut menyebabkan kedinamisan kelompok menjadi rendah. 
Hasil penelitian ini mendukung penelitian Lestari 2012 dalam Ruhimat (2017) yang menyimpulkan belum terjalinnya kerjasama dan komunikasi antara pengurus dengan anggota atau diantara dianggota menyebabkan rendahnya kekompakan dan suasana yang dinamis. Hal tersebutlah yang menyebabkan rendahnya kedinamisan sehingga tingkat kinerja kelompok dalam menjalankan organinisasi kelompok juga menjadi rendah.

\section{Pengaruh Partisipasi Anggota terhadap Kinerja KTH}

Berdasarkan hasil uji signifikansi, Partisipasi Anggota berpengaruh signifikan terhadap Kinerja. Secara umum, Partisipasi anggota di setiap kelompok tani hutan masih tergolong rendah. Melalui diskusi dengan pengurus kelompok diperoleh informasi bahwa tinggat partisipasi anggota kelompok masih belum maksimal dikarenakan kurangnya kesadaran dan rasa memiliki setiap anggota kelompok dalam menjalankan kegiatan KTH.. Hasil penelitian ini mendukung penelitian Pane (2017) yang juga menyatakan bahwa partisipasi anggota berkolerasi signifikan dengan kinerja kelompok tani.

\section{Pengaruh Karakteristik Ketua Kelompok terhadap Kinerja KTH}

Berdasarkan hasil uji signifikansi, Karakteristik Ketua Kelompok juga berpengaruh signifikan terhadap Kinerja. Karakteristik Ketua sebagai Koordinator, Inspirator dan Motivator akan berpengaruh terhadap kinerja kelompok tani hutan.
Menurut Ruhimat I.S (2007) peran ketua kelompok dapat berpengaruh terhadap kedinamisan dan partisipasi anggota kelompok. Hal tersebut tentunya juga akan berpengaruh terhadap kinerja kelompok. Dari hasil diskusi dengan 4 kelompok tani hutan, peran ketua dalam memotivasi dan mengkoordinasi sangatlah penting. Dimana hal tersebut dapat menginspirasi dan mendorong anggota dalam melaksanakan kegiatan kelompok secara aktif.

Selanjutnya, untuk karakteristik anggota, peran penyuluh dan peran UPT KPHP Minas Tahura tidak berpengaruh signifikan terhadap kinerja KTH. Peran penyuluh dan peran UPT KPHP Minas Tahura terhadap kelompok tani hutan dinilai sudah cukup tinggi baik dalam memberikan motivasi, pendampingan, fasilitasi maupun monitoring dan evaluasi. Hanya saja, kinerja dari KTH masih saja rendah. Hal ini dikarenakan kurangnya motivasi kesadaran dari dalam diri individu anggota kelompok dalam menjalankan kegiatan KTH serta kurangnya pengetahuan anggota KTH dalam mengelola kegiatan KTH.

\section{Aspek Kegiatan Yang Dapat Mendukung Kinerja KTH}

Berdasarkan hasil uji signifikansi, yang dapat meningkatkan kinerja kelompok tani hutan ialah tingkat kedinamisan kelompok, partisipasi anggota kelompok dan karakteristik ketua kelompok. Dalam meningkatkan kedinamisan kelompok tani, partisipasi anggota dan karakteristik ketua dapat 
dilakukan dengan menganalisa faktorfaktor yang mempengaruhi ketiga aspek tersebut. Kedinamisan KTH dapat ditingkatkan dengan meningkatkan partisipasi anggota terlebih dahulu dalam setiap tahapan kegiatan. Selanjutnya untuk meningkatkan partisipasi anggota dapat dilakukan dengan meningkatkan peran ketua kelompok tani dalam mengkoordinir, memotivasi, dan menginspirasi anggota kelompok tani.

UPT KPHP Minas Tahura selaku mitra KTH juga dapat berperan langsung dalam meningkatkan ketiga aspek tersebut. UPT KPHP Minas Tahura telah banyak memberikan bantuan kepada KTH khususnya bantuan sarana prasarana pendukung kegiatan budidaya didalam kelompok. Berbagai kegiaan dapat dilakukan oleh UPT KPHP Minas Tahura guna mendukung dan meningkatkan kinerja pada ke empat KTH sehingga kegiatannya dapat berjalan dan usaha yang dikembangkan dapat berjalan dengan baik.

Berdasarkan hasil laporan kegiatan dari UPT KPHP Minas Tahura, diketahui bahwa KTH mitra UPT KPHP Minas Tahura belum memberikan hasil yang cukup maksimal dalam pengembangan budidaya yang dikelola oleh KTH tersebut. Penyebabnya antara lain karena kurangnya pengetahuan anggota KTH tentang budidaya komoditas yang dikembangkan dalam kelompok dan kurangnya motivasi anggota KTH dalam melakukan kegiatan pemeliharaan pada budidaya yang dilakukan.
Langkah-langkah yang dapat dilakukan untuk meningkatkan kinerja KTH yaitu:

a. Penguatan organisasi KTH

Penguatan organisasi KTH dapat dilakukan salah satunya dengan membimbing anggota kelompok tani hutan untuk bekerjasama di bidang ekonomi secara berkelompok sehingga hubungan sesama anggota kelompok menjadi lebih erat (Hermanto dan Swastika, 2011).

Sementara menurut Febryano (2014), penguatan organisasi seyogianya berfokus pada peran dan proses pengambilan keputusan, mobilisasi dan manajemen sumber daya, komunikasi dan koordinasi, serta resolusi konflik.

b. Meningkatkan pembinaan KTH

Pembinaan KTH dapat dilakukan melalui program pemberdayaan dalam pengembangan sumber daya manusia berupa upaya peningkatan kesadaran terhadap anggota kelompok tani hutan. Anggota KTH diyakinkan untuk memiliki kesempatan meningkatkan pendapatan dengan mempelajari aspek sumberdaya yang dimiliki, aspek permodalan, pasar dan teknologi, yang pada akhirnya dapat meningkatkan kesejahteraannya yang menyangkut aspek ekonomi, rohani, kesehatan, pendidikin hukum dan lain-lain.

c. Meningkatkan kemampuan anggota KTH

Peningkatan kemampuan anggota dapat dilakukan dengan berbagai jenis 
pelatihan terkait strategi peningkatan kinerja kelompok, peran serta partisipasi anggota $\mathrm{KTH}$, pelatihan khusus bagi pengurus kelompok tani hutan terkait kepemimpinan dan manajemen pengelolaan organisasi kelompok serta pelatihan terkait pengembangan unit usaha, pengembangan modal dan peluang pasar. Pelatihan tersebut dapat diberikan kepada anggota kelompok secara berkala sehingga kemampuan anggota kelompok dalam mengelola dan mengembangkan kelompok tani hutan lebih maksimal.

d. Meningkatkan jumlah kunjungan, monitoring dan evaluasi

Kinerja KTH juga dipengaruhi oleh jumlah kunjungan. Kunjungan yang dilakukan oleh pegawai KPH sebagai pembina bisa memperlancar komunikasi, memberikan motivasi dan membantu pemecahan masalah yang dihadapi oleh pengurus dan anggota KTH. Selain itu monitoring dan evaluasi terhadap KTH dapat memberikan penguatan dan arah yang benar terhadap program-program KTH. Menurut Suwarno et al., (2015), peningkatan komunikasi, koordinasi, dan penguatan supervisi sangat diperlukan untuk memperlancar kerja yang melibatkan para pihak.

\section{KESIMPULAN DAN SARAN}

\section{A. Kesimpulan}

Berdasarkan hasil penelitian dan analisa data, maka diperoleh kesimpulan bahwa kinerja kelompok tani hutan masih tergolong sedang. Terdapat 6 faktor yang mempengaruhui kinerja KTH, yaitu tiga faktor yang berpengaruh signifikan adalah kedinamisan kelompok, partisipasi anggota dan karakteristik ketua kelompok; sedangkan tiga faktor lainnya yaitu karakteristik anggota, peran penyuluh dan peran UPT KPHP Minas Tahura tidak berpengaruh signifikan.

Aspek yang dapat mendukung kinerja KTH yaitu: (a) Penguatan organisasi KTH; (b) Meningkatkan pembinaan melalui program pemberdayaan pengembangan sumber daya manusia; (c) Meningkatkan kemampuan anggota KTH melalui kegiatan pelatihan dan; (d) Meningkatkan jumlah kunjungan dan kegiatan monitoring dan evaluasi oleh UPT KPHP Minas Tahura terhadap kegiatan KTH.

\section{B. Saran}

Berdasarkan kesimpulan penelitian, maka diajukan beberapa saran sebagai berikut:

a. KTH diharapkan dapat meningkatkan kedinamisan kelompok dengan menjalin kerjasama dan komunikasi yang baik antar sesama anggota, membangun kekompakan kelompok yang lebih erat, serta menjalankan kegiatan kelompok sesuai dengan tujuan, struktur, fungsi, dan peran kelompok.

b. Bagi ketua kelompok agar lebih meningkatkan perannya sebagai pemimpin dalam organisasai kelompok tani hutan khususnya peran sebagai koordinartor, inspirator dan motivator 
bagi anggota kelompok sehingga anggota kelompok lebih termotivasi dalam mengembangkan kegiatan KTH.

c. Bagi anggota KTH agar meningkatkan pengetahuan, keterampilan, peran dan partisipasi nya dalam menjalankan kegiatan KTH dimulai dari kegiatan perencanaan, pelaksanaan, pemeliharaan, pemanfaatan hasil hingga kegiatan monitoring dan evaluasi.

d. Bagi UPT KPHP Minas Tahura selaku mitra KTH agar memberikan dukungan terhadap peningkatan kinerja kelompok dengan mengotimalkan pelaksanaan pelatihan, pendidikan dan pembinaan yang berkaitan dengan hal-hal yang dapat meningkatkan kinerja KTH.

\section{DAFTAR PUSTAKA}

Abdillah, W., Jogiyanto. (2015). PLS (Partial Least Square)-Alternatif Structural Equation Modeling (SEM) dalam penelitian bisnis. Yogyakarta: Andi.

Cuaresma, J.C., et al. 2017. Economic Development and Forest Cover: Evidence from Satellite Data. Scientific Reports, $\quad 7: 40678 . \quad$ DOI: $10.1038 /$ srep40678

Febryano, I.G. et all. (2014). The Roles and Sustainability of Local Institutions of Mangrove Management in Pahawang Island. JMHT $\mathrm{XX}(2)$ : 69-76. DOI: $10.7226 / \mathrm{jtfm} .20 .2 .69$

Hermanto, R., Swastika, D.K.S. (2011). Penguatan Kelompok Tani: Langkah Awal Peningkatan Kesejahteraan Petani. Jurnal AKP 9(4), 371-390
Jogiyanto : Abdillah (2009). Konsep dan Aplikasi PLS. BPFE-Yogyakarta

KPHP Minas Tahura. (2016). Rencana Pengelolaan Hutan Jangka Panjang KPHP Minas Tahura Tahun 2016-2025. Pekanbaru: KPHP Minas Tahura.

Lestari, G. I. (2012). Dinamika kelompok tani hutan rakyat di Desa Lemahduhur. (Tesis). Bogor: Sekolah Pascasarjana Institut Pertanian Bogor

Pane Y.E. (2017). Hubungan Partisipasi Anggota Dengan Kinerja Kelompok Tani. Studi Komparasi Kelompok Tani Karya Murni dan Kelompok Tani Lestari, Desa Buyut Ilir Kec. Gunung Sugih Kabupaten Lampung Tengah. [Skripsi]. Bandar Lampung: Fakultas Ilmu Sosial dan Ilmu Politik U.niversitas Lampung.

Ruhimat, I.S. (2017). Peningkatan Kapasitas Kelembagaan Kelompok Tani dalam Pengembangan Usaha Tani Agroforestry di Desa Cukangkawung. Jurnal Penelitian Sosial Ekonomi Kehutanan, 14(1), 1-17.

Siswoko, B.D. 2008. Pembangunan, Deforestasi dan Perubahan Iklim. JMHT XIV (2): 88-95

Soe, K.T., Yeo-Chang, Y. 2019. Livelihood Dependency on Non-Timber Forest Products: Implications for REDD+. Forests 10,427. doi:10.3390/f10050427

Sugiyono. (2012). Metode Penelitian Kuantitatif Kualitatif dan $R \& D$. Bandung: Alfabeta.

Suwarno, E., Hadinoto, \& Suhesti, E. (2018a). Transformation of the Palm Oil System in the Conservation Village in Riau, Indonesia. IOP Conference Series: Earth and Environmental Science, 175(1). 
https://doi.org/10.1088/1755-

1315/175/1/012106

Suwarno, E., Hadinoto, \& Suhesti, E. (2018b). Village Conservation Program: Community Readiness Assessment and Strategies Arrangement. IOP Conference Series: Earth and Environmental Science, 175(1). https://doi.org/10.1088/17551315/175/1/012063

Suwarno, E., Kartodihardjo, H., M Kolopaking, L., \& Soedomo, S. (2015). PENGGUNAAN KONSEP RULES IN USE OSTROM DALAM ANALISIS PERATURAN PEMBENTUKAN ORGANISASI KESATUAN PENGELOLAAN HUTAN. Jurnal Analisis Kebijakan Kehutanan, 12(1), 13-26.

https://doi.org/10.20886/jakk.2015.12.1.1 3-26 